\section{IUCN Red List of Threatened Animals}

A quarter of all known mammal species are at risk of extinction, according to the new 1996 IUCN Red List of Threatened Animals. Until this new assessment, the conservation world has used the status of birds to estimate the level of threat to all animals because birds were the only group of species that had been fully assessed. Now it is known that 11 per cent of all known bird species are threatened with extinction, as are 20 per cent of reptiles, 25 per cent of amphibians and 34 per cent of fish, mostly freshwater species.

More than 100 species of marine fish were added to the 1996 Red List, including sharks, tuna, coral reef fish and seahorses. While the status of the remaining 14,000 marine species has yet to be assessed, the recent additions indicate that many marine species could be at higher risk than previously thought. All species of sturgeons and paddlefish were found to be threatened or near threatened (see page 1 of this issue). Many freshwater species from other groups are also classified as threatened because land-use changes, pollution and channel modification have led to the deterioration of freshwater habitats world-wide.

The Red List contains 5205 species assessments conducted by more than 500 members of IUCN's Species Survival Commission. More rigorous criteria were used to assess the conservation status for the 1996 Red List than in previous editions. The new list provides alternative approaches to assessing threat, such as population decline, fragmentation of populations or low population numbers. Different scientific approaches were used to assess levels of endangerment, including the rate of population decline over a 10-year period. Using this criterion, critically endangered species are defined as those experiencing an 80 per cent decline, endangered a 50 per cent decline and vulnerable, a 20 per cent decline.

Of the 26 orders of mammals, 24 include threatened species and the six largest orders have more than 50 threatened species each. The highest proportion of threatened species are in the primates (46 per cent); insectivores (36 per cent); artiodactyls - pigs, antelopes and cattle ( 33 per cent); bats ( 26 per cent); carnivores (26 per cent) and rodents (17 per cent). Of the 27 orders of birds, 23 contain threatened species, with the five orders containing the highest number being those that include rails and cranes ( 26 per cent), pheasants and partridges (25 per cent), parrots ( 25 per cent), pigeons and doves (17 per cent) and kingfishers and bee-eaters (12 per cent).

Among reptiles, 44 per cent of the 23 species of crocodilians are threatened but this is one group of animals where improvements in status have occurred. In 1971 all 23 species were endangered. Today seven are abundant enough to allow sustainable use for trade in skins and five have stable or increasing populations.

Very few invertebrates have been assessed relative to their total numbers: those that have received most attention are crustaceans, insects and molluscs. More threatened molluscs are included in the Red List than any other invertebrate group. Out of 70,000 documented mollusc species, some 2049 were assessed and 920 identified as threatened.

The 1996 IUCN Red List of Threatened Animals is available on the World Wide Web at: http://www.iucn.org/themes/ssc/index.html

Editor

\section{Species survival versus perpetuation of myth - the case of the Philippine eagle}

Two days before New Year 1997 the Philippine eagle Pithecophaga jefferyi reached its centenary in zoological nomenclature. Its discovery in June 1896 during exploratory work on Samar by John Whitehead was an astonishing event, on the scale of the finding of the okapi Okapia johnstoni, the Congo peafowl Afropavo congensis and the recent large ungulates from Vietnam. So many explorers, including Whitehead himself, had missed it for so many 
years; and this was not some small retiring nondescript but just about the world's largest raptor and, as it turned out, the top rain-forest carnivore in the four largest islands - Luzon, Samar, Leyte and Mindanao - of the main Philippine archipelago.

Nevertheless, in the first 67 years after its discovery the only interest shown in the species was by an anatomist exploring its affinities, and by foreign museums and zoos wanting to acquire specimens. Indeed, it was the intensifying zoo trade around 1960, coupled with excessive local trophy-hunting, that prompted the late D. S. Rabor to set one of his students on a field study of the species in 1963-64 (Gonzales, 1968). The history of eagle research and management since that pioneering study illustrates some interrelated problems in conservation assessment, including the way assumptions made in one generation of fieldwork become truths in the next, how over-cautious interpretations of data promote possibly inappropriate management responses, how long-term projects develop self-justifying datasets, and how very lowcontact species generate distorted beliefs in the degree of their rarity.

To begin with, in setting Gonzales's project up, Rabor (1965) had pronounced the bird extinct on Samar and Leyte; and almost so on Luzon (in spite of inexplicably contrary testimony he published elsewhere: see Collar et al., in press), and this opinion, based on his own field experience, was accepted uncritically for at least a decade (ironically, it is Luzon that is now thought may possess the largest and most secure population of the species). Moreover, he declared that no more than 40-50 pairs could possibly survive on Mindanao, the first in a long line of underestimates that have crucially influenced the way conservationists have responded to the species's needs.

Next, Gonzales (1968) decided that the pair of eagles whose nest he studied ranged over an area of 'at least' $100 \mathrm{sq} \mathrm{km}$, a casual, unsupported, one-off remark that has likewise profoundly affected the conservation effort. Gonzales (1969), Kennedy (1977), Bonnit et al. (1977) and Krupa (1989) all used this value in calculating population sizes, none of them explaining why, even though at least four lower values for an eagle territory, ranging from 12.5 to $50 \mathrm{sq} \mathrm{km}$, have been suggested by or can be adduced from other - and even their own fieldwork (see Collar et al., in press).

Kennedy (1977) was particularly diffident. Having ascertained from maps, photographs, overflights and site visits that approximately $29,000 \mathrm{sq} \mathrm{km}$ of forest remained on Mindanao, he applied the $100-\mathrm{sq}-\mathrm{km}$ value to obtain a population of 580; but he also conducted fieldwork in $640 \mathrm{sq} \mathrm{km}$ of this area and, having seen nine eagles, extrapolated a total of 408 ; moreover he undertook surveys and interviews within roughly one-third of the available habitat, saw 29 birds and learnt of 74 more (i.e. 103, excluding 35 reported captured or killed), and extrapolated a Mindanao total of 309. This last, although it startlingly assumes a 100 per cent encounter rate and yields a density of one pair per $188 \mathrm{sq} \mathrm{km}$, was the one he decided was most appropriate (despite a $12.5-\mathrm{sq}-\mathrm{km}$ home range in birds he studied, which suggested to him 'that the area necessary to support a pair of eagles may not be as great as formerly believed'). As a consequence of his own and others' frequent repetitions, the notion that there are or then were roughly 300 eagles on Mindanao (he allowed another 100 for the remaining three islands) quickly gained currency.

Kennedy may well have felt constrained by earlier estimates, which he was substantially revising: to have suggested that Mindanao might harbour 4640 birds (one pair per $12.5 \mathrm{sq}$ $\mathrm{km}$ in $29,000 \mathrm{sq} \mathrm{km}$ ) when the most recent prior estimate was 52 - Alvarez (1973) having accepted there were 'about 5 to 6 pairs more' than the 40 birds he had estimated in 1970 could perhaps have exposed his work to ridicule. Nevertheless, the full range of possibilities was not allowed (including, incidentally, the factoring in of immature or unpaired birds), and the sense of desperate crisis relating to the eagle was not dispelled: an immediate upshot was the establishment of a captivebreeding programme, which for the past 15 years has been the dominant feature of conservation work directed at the species. 
Once the ex situ programme was launched, that sense of crisis in the wild, perhaps unsurprisingly, only deepened. Thus Krupa (1989) declared that eagles cannot traverse gaps between forest patches greater than $20 \mathrm{~km}$, and cited five instances where birds were 'downed' in the attempt. Alternative explanations, such as that these were old, wounded or diseased birds, or inexperienced starving youngsters, were not considered, even though the literature reveals that adults will sometimes soar to great heights, which suggests they must be able to cover large distances (again see Collar et al., in press). However, if each isolated forest area (Krupa identified 37) is believed to contain an equally isolated and, without intervention, probably unviable population of eagles (Krupa argued that 'genetic bottleneck can occur at less than 50 individuals' and, once more using the 100-sq-km value, predicted that only two of his 37 fragments held more), the case for taking birds into captivity greatly improves.

With the $100-\mathrm{sq}-\mathrm{km}$ value the total holdings of pairs of birds in these 37 fragments (total area $22,170 \mathrm{sq} \mathrm{km}$ ) was found to lie in the range 89-222 (Krupa having allowed for 40-100 per cent habitat occupancy), fairly close to Kennedy's estimate a decade earlier. Most recently, however, both Salvador (1994) and PEWG (1996) have mistaken Krupa's numbers as referring to individuals, not pairs, so the population has been halved at a stroke. Worse, PEWG (1996), an official document with ministerial approval, lists the number of birds recently sighted (60) in a table labelled as the 'Total Wild Population', to which is then added the 17 captive animals plus two suspected extras, making 'a total of 79 birds [that] could be counted for the entire species'. One cannot help noticing the convergence of 79 and 89 (inevitably suggesting support for the lower of Krupa's already halved and in any case highly cautious values).

This all tends to reinforce the view that $e x$ situ management is vital to the eagle. However, any programme that has cost a great deal of money over the years will inevitably seek to portray itself as necessary and relevant, and if caution is needed anywhere it is surely in the evaluation of current management options, based on the best possible information, irrespective of previous investments. There are many reasons for concern about captive breeding, not least the issues of disease transmission to wild birds and the programme's current need for eggs or eaglets from wild nests. Moreover, if it may take fledged birds 6 months before they can catch their own food, and a year on top of that before they are adequately independent to quit the protection of their parents' territories (Kennedy, 1985), the question of how (and at what expense) any captive-bred bird can be trained in a way that begins to match such long-term preparation for self-sufficiency is something that requires urgent airing.

Most basic of all, however, is the nagging doubt that any captive effort is really appropriate. Because, in any case, captive breeding only makes sense if there is somewhere to return the birds to, the greatest emphasis must fall on habitat preservation; and what that habitat might yet be found to contain, even at this late stage in the degradation of the Philippine environment, is worth considering afresh. Right back at the start Ogilvie Grant (1897) had observed:

That so large a Raptor should have remained unknown till the present time only shows how easily these great Forest-Eagles may be overlooked. As an instance of this, it is worth mentioning that during the years Mr Salvin spent collecting birds in Central America he only once saw a Harpy Eagle [Harpia harpyja]. The fact is that in the dense and lofty forests where these birds make their home it is almost impossible to see them.

All the evidence tends to suggest that this perception is correct: it explains why the eagle went undetected by so many early explorers for so long, how Rabor failed to find it on Luzon, Samar and Leyte, and how the rates at which birds were reported killed or captured could have been as high as they were, e.g. 35 in 40 months (Kennedy, 1977), or 12 shot in 12 years by a single hunter at Mt Matutum 
(Gonzales, 1971). It is, at any rate, encouraging to learn that very recent analysis of harpy eagle density throughout its range now shows the species living at roughly one pair per $13-60 \mathrm{sq} \mathrm{km}$, depending on the fertility of the soil (E. Alvarez Cordero, pers. comm.). Philippine soils are, for the most part, very fertile.

None of this is to argue that the Philippine eagle is not a highly threatened species deserving our full attention; it is simply to suggest that the attention we need to give it is in the wild. The underestimation of population sizes is a common phenomenon (see Gaston, 1994), and it is this, other than the appalling loss of habitat in so much of its range, which may well emerge as the fundamental problem afflicting the Philippine eagle in recent years. Whether so magnificent an animal will live to see its bicentenary is not a question we should even have to ask; but I worry that it will only get that far if the myths about it do not.

\section{References}

Alvarez, J.B. 1973. Project 610 Monkey-eating eagle conservation. In World Wildlife Fund Yearbook 1972-73 (ed. P. Jackson), pp. 144-148. WWF, Morges, Switzerland.

Bonnit, C.B., Rundquist, L. and Rundquist, V.M. 1977. Population, territoriality and recommendations for conservation of the monkeyeating eagle Pithecophaga jefferyi, in the Davao Provinces. Pterocarpus, 3, 87-100.

Collar, N.J., Tabaranza, B.R., Mallari, N.A.D. and Villasper, J. In press. Threatened birds of the Philippines. Bookmark in association with BirdLife International, Manila.

Gaston, K.J. 1994. Rarity. Chapman and Hall, London.

Gonzales, R.B. 1968. A study of the breeding biology and ecology of the monkey-eating eagle. Silliman Journal, 15, 461-500.

Gonzales, R.B. 1969. Monkey-eating eagle survey, Mindanao Island, Philippines. In World Wildlife Fund Yearbook 1969 (ed. F. Vollmer), pp. 116-119. WWF, Morges, Switzerland.

Gonzales, R.B. 1971. Report on the 1969 status of the monkey-eating eagle on Mindanao Island, Philippines. Bull. ICBP, 11, 154-168.

Kennedy, R.S. 1977. Notes on the biology and population status of the monkey-eating eagle of the Philippines. Wilson Bull. 89, 1-20.
Kennedy, R.S. 1985. Conservation research of the Philippine eagle. National Geographical Society Research Reports, 18, 401-414.

Krupa, R.E. 1989. Social and biological implications for endangered species management: the Philippine eagle Pithecophaga jefferyi. In Raptors in the Modern World (eds B.-U. Meyburg and R. D. Chancellor), pp. 301-314. World Working Group on Birds of Prey, Berlin.

Ogilvie Grant, W.R. 1897. On the birds of the Philippine Islands. Part IX. The islands of Samar and Leite. Ibis, (7) 3, 209-250.

PEWG (Philippine Eagle Working Group). 1996. Integrated Conservation Plan for the Philippine Eagle (Pithecophaga jefferyi). Approved 8 March 1996 by Victor O. Ramos, Secretary, Department of Environment and Natural Resources. Unpublished.

Rabor, D.S. 1965. The present status of the monkeyeating eagle, Pithecophaga jefferyi Ogilvie Grant, of the Philippines. In Conference on Conservation of Nature and Natural Resources in Tropical South East Asia, Bangkok, Thailand, November 29-December 4, 1965, pp. 55-63. International Union for Conservation of Nature and Natural Resources, Morges, Switzerland.

Salvador, D.J.I. 1994. Socio-economic incentives for the conservation of the rainforest habitat of the Philippine eagle Pithecophaga jefferyi. In Raptor Conservation Today (eds B.-U. Meyburg and R. D. Chancellor), pp. 277-282. Pica Press/World Working Group on Birds of Prey, Robertsbridge, UK.

N. J. Collar BirdLife International, Wellbrook Court Girton Road, Cambridge CB3 ONA, UK

\section{The Niger Delta colobus - discovered in 1993 and now in danger of extinction}

In 1993 a population of red colobus monkeys, until then unknown to occur between Ghana and Cameroon, was found in a very limited area of the Niger Delta in Nigeria (Powell, 1993). The population is being described as a new subspecies of Procolobus badius (sensu lato) in the pennantii group (C. B. Powell and P. Grubb, pers. comm.). Their distribution appears to be restricted to the 'marsh forest' zone - the freshwater tidal sector with permanently 
water-logged ground that does not receive much of the annual Niger flood (Powell, 1993). The swamps within this area are, like the other swamps in the delta, dominated by Raphia spp., abura Hallea ledermannii and Symphonia globulifera.

Local reports collected by Powell (1993) indicated that the Niger Delta red colobus was common over much of its range of approximately $600 \mathrm{sq} \mathrm{km}$. This was confirmed by primatologists visiting Gbanraun, where the monkeys were easily seen, and the population appeared to be in no immediate danger (Oates, 1994). New fieldwork by J. L. R. Werre, however, indicates that the situation is more alarming than first realized. When Gbanraun was revisited in 1994 the trees where the monkeys had been observed were being cut down and during the survey of the rest of the forest no monkeys were encountered.

Red colobus are found only in and around the permanent swamps that characterize their distribution area. Although hunters say that the animals spend some time in the dry forest ridges during certain parts of the year, most foraging takes place in the swamps where abura appears to be their most important food species. All these areas, such as EgbemoAngalabiri, which had been identified as possible prime red colobus habitat (Powell, 1993) were found to have been logged to such a degree that no abura were left. Everywhere rafts of logs were seen lining long stretches of creek and only a few remote areas were untouched by logging. These areas were generally old river levees, which remain unlogged because the removal of timber from dry land is more labour-intensive than in the swamps, where logs can be floated out. The only unlogged swamps were located in the beach-ridge forest zone outside the monkey's range.

There are other factors associated with logging, oil exploration and transportation that may also affect the survival of the colobus population. Ditches, often more than $1 \mathrm{~km}$ long, are dug to float logs out of the swamps to the creeks and they function as drains when the water recedes, altering the hydrological regime. Another problem is the large canals made by the oil companies and the govern- ment to reach well-drilling locations or to shorten travelling distances. These also interfere with the hydrology and may convert permanent swamps into seasonal ones.

The restricted distribution area of the colobus and the high level of human activity in the Niger Delta place the population under severe threat. From the data collected so far, it is clear that most of the distribution area has become, or is the process of becoming, unsuitable habitat. Hunters said that the red colobus was one of the most common primate species in the area but that 'the noise of the chain saw' had driven them away. If degradation continues it is unlikely that this population will survive far into the next century.

There are no conservation areas in the red colobus's range. After the discovery of the monkeys, hopes had been raised for a conservation effort (Oates, 1994). A forest reserve, Apoi Creek, near Gbanraun had been proposed and surveyed, only remaining to be officially gazetted. This is unlikely to happen in the near future with the Rivers State Forestry Department's budget being about \$US6750 for 1995 (Moffat and Linden, 1995). Currently a few organizations have shown interest in a conservation effort within the red colobus's range. Although the interest is encouraging, more concrete conservation efforts are needed and, given the rate at which the forest is being destroyed, immediate action is essential.

\section{Acknowledgements}

J. L. R. Werre works through the Niger Delta Wetlands Centre and is supported with grants from the Nigerian Agip Oil Corporation, Primate Conservation Inc., and Zoological Society for the Conservation of Species and Populations. C. B. Powell is on the research staff of the Institute of Pollution Studies in the Rivers State University of Science and Technology, Port Harcourt. His work is partly funded by the Shell Petroleum Development Corporation of Nigeria Ltd.

\section{References}

Moffat, D. and Linden, O. 1995. Perception and reality: assessing priorities for sustainable development in the Niger River Delta. Ambio, 24, 527-538. 
Oates, J.F. 1994. The Niger Delta's red colobus monkeys: a new subspecies? African Wildlife Update, March/April, 4.

Powell, C.B. 1993. Sites and Species of Conservation Interest in the Central Axis of the Niger Delta (Yenagoa, Sagbama, Ekeremor and Southern Ijo Local Government Areas). A Report of Recommendations. Report to the Natural Resources Conservation Council, Abuja, Nigeria.

J. L. R. Werre Department of Anthropology, Hunter College 695 Park Avenue, New York, NY 10021, USA

C. B. Powell

PO Box 173, Uniport Post Office Port Harcourt, Nigeria

\section{African elephant range states meet in Senegal}

From 11 to 16 November 1996 Ministers and senior officials from 31 African elephant range states met in Dakar, Senegal, to discuss issues affecting the future of the African elephant. Delegates addressed the question of trade in ivory and other derivatives. The meeting originated in a decision of the range states at the 1994 CITES meeting in Fort Lauderdale that they should pursue the objective of a dialogue, seeking consensus on issues that had divided them at recent CITES gatherings. It was not designed to take up formal positions, but to share information and build understanding. A substantial communiqué was agreed.

In the opinion of the delegates and the observers from donor governments this objective was fully achieved. The meeting was well organized by IUCN on behalf of the CITES Africa members of the Standing Committee. The atmosphere was serious but good humoured. If there were any tensions they were within rather than between delegations. An increasing convergence on management and sustainable-use strategies could be detected. Equally encouraging were frank admissions on the part of some countries that their information and security arrangements fell short of what was needed.

Botswana, Namibia and Zimbabwe were able to present the proposals for downlisting their elephant populations from Appendix I to Appendix II of CITES, which they will be bringing to the next meeting of the Conference of the Parties in Harare in June. Prepared in close collaboration, the proposals envisage a re-opened trade in raw ivory of a strictly limited nature. Each country would send only one shipment a year for 2 years to Japan. Quantities were not yet determined, but in principle would not exceed the current stockpile each country is holding. The three Southern African countries invited comments and suggested improvements, both at the meeting and afterwards up to the time of formal submission in January 1997.

Other delegations did not meet formally, but welcomed the open approach being taken. Japan's internal ivory control system was also explained and Sudan announced its wish to resubmit the proposal put at Fort Lauderdale for disposal of its stockpile. A range of penetrating questions was asked and some useful explanations given in return. The Southern Africans were more than pleased with the measured reaction and reiterated their wish for further dialogue before the proposals were finalized. Comments from the CITES Panel of Experts were awaited.

New elephant population estimates gave figures of 79,000 for Botswana and 67,000 for Zimbabwe. The TRAFFIC representative was able to gather fresh information on ivory stocks in a number of countries, bringing the identified total to over 400 tonnes. It was clear that while government stockpiles in East and Southern Africa are growing significantly, those in West and Central Africa (in so far as they exist at all) are not, and there are no upto-date figures for private stock in these regions. Delegates who visited the Dakar markets were able to see raw ivory in the form of tusks on open display and the ivory carvers were quite ready to talk about its nonSenegalese origin. The pattern emerging from many data sources is of raw ivory coming mainly from Central Africa being worked by 
West African carvers in a number of countries either for the tourist market or, under the direction of Asian entrepreneurs, for the nameseal market in the Far East.

Senegal's Environment Minister, who opened the meeting, spoke eloquently about the significance of elephants for Africa and called for a spirit of compromise to guide the discussions. The outcome more than met his challenge. It remains to be seen whether the same spirit will prevail in Harare. In any event Dakar was an important milestone in asserting African responsibility for the largest and most fascinating of land animals.

Robin Sharp, FFI Trustee

\section{Thailand's expanding green peafowl population}

The green peafowl Pavo muticus population in the Huai Kha Khaeng Wildlife Sanctuary of west Thailand is recolonizing former territories in the Thap Salao Valley near the sanctuary's headquarters some $30 \mathrm{~km}$ east of the sanctuary's main river valley, the Huai Kha Khaeng itself. With around 300 birds, this sanctuary supports one of the largest and least threatened green peafowl populations in Asia.

The Thap Salao Valley was once home to green peafowl, but forest settlers eliminated them and their cohabitants. Then, 5 years ago, after the much lamented suicide of sanctuary chief Seub Nakhasathien, the boundary was extended eastwards, villagers were given new land outside the valley and it reverted to a natural, undisturbed state. Now it has been recolonized by gibbons, green peafowl, otters, deer and jackals.

The pioneering peafowl, around 10 in total appear to be subadult males and females. Although no one knows what route they took, they can only have come from the valley of the Huai Kha Khaeng and must have followed a series of streams before flying across the dividing watershed ridge. But that any birds came at all and that those that came are subadults suggests that the main population may have reached its carrying capacity. A survey in 1993 (10 years after the first, 5 years after the second) indicated a population increase of around 20 per cent.

The two most notable changes in Huai Kha Khaeng over the last 5 years have been a dramatic reduction in poaching and forest fires, which would have helped the peafowl population prosper. In 1993 it was already apparent that the peafowl had extended its range within the valley to areas that were not inhabited before and are, apparently, marginal habitat. But only now are young birds looking for territories outside the valley of their birth.

Seub Nakhasathien's successor, Chatchawan Pisdamkham, can be given most of the credit for this dramatic improvement in the sanctuary's conservation status. When he took over the tricky job of chief, he introduced a tough but visionary programme of policing, staff training and welfare, and public relations (largely funded by the Seub Nakhasathien Foundation), which slowly transformed Huai Kha Khaeng from a sanctuary where morale was low and offences high to one that qualifies as a model conservation area. Proof of this is plentiful but none is more conspicuous than the peacock calls that chime the working day around the sanctuary headquarters after a silence of almost three decades.

Belinda Stewart-Cox The Seub Nakhasathien Foundation 50 Phaholyothin Road, Bangkok 10900, Thailand

\section{The AfriCat Foundation}

The AfriCat Foundation was formed in November 1992 by Wayne and Lise Hanssen on their 6000-ha farm, Okonjima, at Otjiwarongo in the Omboroko Mountains of the Waterberg Plateau, $200 \mathrm{~km}$ north of Windhoek, to conserve the big cats of Namibia.

For the previous 15 years Wayne Hanssen had been studying leopards Panthera pardus at Okonjima and had been attempting to devise 
effective methods to prevent leopard predation on domestic stock. Since early 1991 Lise Hanssen has been conducting a parallel study of leopards and cheetahs Acinonyx jubatus on other farms in Namibia and has been successfully breeding cheetahs at Okonjima. Initially their work was funded by tourists visiting the farm, but when the project grew too large to be supported in this way, the Hanssens formed the AfriCat Foundation to raise funds elsewhere.

The staff comprises the Hanssens, Wayne's two sisters, Donna and Rosalea, plus a team of trained professionals and experienced fieldworkers. All understand the problems caused by predators to local farmers and can offer advice and help on this sensitive issue in a way that does not give offence.

Of the world population of $9000-12,000$ cheetahs, Namibia supports some 2500 - the largest surviving free-ranging population. Only 5 per cent of these are found within Namibia's national parks, the rest occurring on the 6000 or so privately owned farms.

In Namibia, as elsewhere in Africa, inadequate methods of protecting livestock have resulted in severe losses; shepherds lose sheep and lambs to cheetahs and leopards, as well as to raptors and caracals Felis caracal; cattle ranchers lose calves to cheetahs and leopards, and cows to lions Panthera leo and spotted hyaenas Crocuta crocuta. Livestock farmers whose sole income is derived from their stock, can ill afford such losses and most regard predators as vermin, seeing their eradication as the only real solution to their problem. This is achieved by capture in box-traps or gintraps, which are placed at cheetah's play-trees or on leopard kills. Once caught the animals are shot or sold to dealers.

The removal of a predator does not necessarily solve the farmer's problem, however, and may even make the situation worse. The vacant territory will usually be promptly filled by another animal and, while the animal that had been removed might not have been the one that was causing a problem, its replacement may be a killer of stock. Namibia's Department of Nature Conservation estimates that in just over a decade almost 7000 cheetahs have been removed from the country's freeranging population.

It has been shown that, rather than trying to eliminate predators, it is more profitable for stock farmers to take preventive measures to protect their animals. One of the most effective means of protection is to keep young calves in a predator-proof enclosure near the house, with the cows entering the enclosure to suckle their calves and returning to the veld to graze. This procedure has two other advantages: the calves become accustomed to human contact and are less skittish when adult; and farmers can monitor the condition of cows more easily.

It can be advantageous for farmers to establish a primary calving season between November and January and a secondary one in June. Synchronous calving in an enclosure is clearly preferable to asynchronous calving in the veld, and the birth of most calves in the wet season ensures better quality grazing after weaning. The wet season is also the time when wild antelopes give birth and the predators' natural prey - weak, sick or injured young antelopes - is abundant: the result - a strong and healthy antelope population and a reduction in the number of livestock killed.

Game farmers who have invested in expensive antelope species have found that electric fencing in conjunction with enclosures provides effective protection. Farmers who prefer to keep their stock in a kraal near the house at night have found that the inclusion of female donkeys, which are naturally aggressive and protective and which will readily kick and bite cheetahs, can offer effective defence. Some sheep farmers protect their animals by including chacma baboons Papio papio ursinus in the flocks; the baboons behave as if the sheep were members of the troop and defend them against predators. Guard dogs living with small domestic stock can prove effective deterrents against cheetah attacks and the inclusion of horned cattle in a calving herd can also keep predators at bay.

A short-term goal is the release of non-problem predators caught in traps back into the wild to maintain a healthy free-ranging population and to stabilize the territories of these predators on farmland. Farmers trapping a 
predator telephone the Foundation and staff go immediately to the capture site. The animal is anaesthetized for data-collection and eartagging, photographed to enable subsequent recognition (the spot pattern is individually unique) and removed from the farm.

If the animal is in good condition and has not been killing stock, it is released almost immediately. Because leopards normally return to their kills, traps set near the carcasss of a domestic animal will usually catch stock killers but sometimes a farmer will set a trap near the carcass of a game animal, thinking it best to remove the leopard before it kills livestock. In the case of cheetahs caught in traps set near play-trees, it is more difficult to determine whether the captured animal is a stock killer. The farmer is asked when he last lost a domestic animal; if it was more than a week before, the captured cheetah is unlikely to be guilty because cheetahs seldom remain in one area for very long.

If the captured animal is in poor condition it is rehabilitated at Okonjima for subsequent relocation. If it cannot be rehabilitated it will be retired to one of the large enclosures at Okonjima. Problem predators are never released back on to farmland.

If a farmer is continually losing stock to predators, a study is made of his land to determine why this is happening. The farmer becomes part of the project and is free to seek the Foundation's help and advice at any time. The expenses of the operation, including transport, relocation, feeding and normal veterinary expenses are covered by the Foundation. If specialized attention is required - for example to deal with limbs and teeth broken in gin-traps or poisoning from treated carcasses - emergency air transport and veterinary care are provided at cost by the Otjiwarongo Veterinary Clinic and the Foundation's trustees.

In 1993 and 1994 the Foundation released nearly 40 and more than 60 predators, respectively, back into the wild, and by early 1996 had released over 100 cheetahs and 60 leopards. These were all non-problem animals, which would have been shot were it not for the Foundation's efforts. The number of farmers who have asked the Foundation for assistance has increased, many of them contacting it several times. Some farmers have stopped trapping predators and are trying to improve their methods of stock protection.

Numbered ear tags bearing the Foundation's telephone number are used to mark released animals. If a predator is recaptured its movements can be established and its destruction prevented. If it is identified as a stock killer, it can be relocated to a stock-free area. Although ear-tagging allows animals to be identified if caught, it cannot be used to determine complete movement patterns since release. The Foundation hopes to address this problem. eventually by the use of radio-telemetry.

Of the 119 predators released by May 1995, four had been shot but not because of killing stock, two were caught in gin-traps and shot, one was shot on sight and one was taken in a box-trap and shot. Thus 111 benign predators acquired territories and kept potential problem animals away from livestock areas.

A medium-term goal is to inform farmers of tried-and-tested antipredator husbandry methods. The Foundation has developed four kinds of electric fencing to deter predators. It has persuaded several sheep and cattle farmers as well as game ranchers to have electric fencing erected on their properties. The owners bear the cost and maintenance of the fencing erected by the Foundation if it proves effective, and the Foundation pays for its removal if it proves ineffective.

A long-term goal of the Foundation is to develop measures for farmers who suffer repeated losses of livestock. The Foundation is continuing to experiment with new forms of electric fencing and is testing a mobile, predator-proof enclosure made of collapsible, heavy-gauge diamond-mesh wire netting. In the case of problem predators that kill only livestock instead of their natural prey, the Foundation is working on a form of aversion therapy, designed to make predators associate livestock with unpleasant experiences.

Another long-term goal is education. The Foundation plans to establish an education centre at Okonjima; topics covered will range from overgrazing, bush encroachment and the stock-carrying capacity of land, to livestock 
protection and predator conservation. The education of children - the farmers of the future is vital for the future of the country's wildlife. Groups of farm children have visited Okonjima, where they have seen the effectiveness of electric fencing against predators, have been shown the importance of predators in the ecosystem and have been able to see leopards and cheetahs at close range. After visiting Okonjima children have persuaded their parents to release, unharmed, captured predators.

Two other long-term goals are to establish conservancies and provide opportunities for scientific research on predators. The Foundation plans to co-operate with landowners in the development of conservancies to improve land use, including the management of antelopes, predators and the veld. This would result in opening up larger expanses of land and the effective use of these areas would be determined by the landowners themselves. Predators would have their place in these areas and would help to maintain a healthy antelope population and provide an income-generating resource through tourism.

The AfriCat Foundation can be contacted at PO Box 793, Otjiwarongo, Namibia. Tel: 0651 304563/4; fax: 0651 304565; e-mail: africat@iwwn.com.na

Sir Christopher Lever, Bt Newell House, Winkfield Berkshire SL4 4SE, UK

\section{Dog vaccination around the Serengeti}

In the July 1996 issue of Oryx (30 [3], 169), the 'Briefly' item 'Dogs to be vaccinated around Serengeti' interested me.

The discussions about transmission of domestic dog diseases to wildlife - mainly wild canidae, but also to most wild carnivora - is of real concern. Recent issues of Oryx have already mentioned this problem, as well as periodicals such as Nature and Science. Rabies and canine distemper are two viral diseases that can be prevented by vaccination but I shall mainly speak of distemper here.

The problem is that if an attenuated vaccine, rather than a dead vaccine, is used against distemper, the vaccinated animal is protected but may become a virus carrier. It must also be understood that distemper may have a regulating effect on the dog populations around national parks, which more and more resemble islands surrounded by farmlands. So, if the vaccination campaign is a success, the result may be more dogs, more virus and more threats to wildlife (for example wild dogs Lycaon pictus in Tanzania, and Simien fox Canis simensis in Ethiopia). Another problem is that vaccination is only effective for a few months or years. Is there a plan to vaccinate dogs every year? Who will pay for that? One or two vaccination campaigns may end with a situation worse than before. It could be, in the long term, more effective to look for a way of controlling the domestic dog population, or at least to use both approaches together, mainly around national parks. Unless this is done, I see no real hope for the survival of many wild carnivores.

$$
\begin{array}{r}
\text { François Moutou, DVM } \\
\text { IUCN/SSC Veterinary Specialist Group } \\
\text { CNEVA Alfort, Unité d'Epidémiologie } \\
22 \text { rue Pierre Curie } \\
\text { BP 67,94703 Maisons-Alfort, France }
\end{array}
$$

\section{Sarah Cleaveland replies}

Dr Moutou has three main concerns about the proposed domestic dog vaccination programme against distemper and rabies in the vicinity of the Serengeti National Park. First, he raises the possibility of virus excretion in vaccinated animals as a threat to wildlife populations. Second, he questions whether dog vaccination might lead to an increase in dog abundance and hence exacerbate disease risks. Third, he considers the issue of sustainability of dog vaccination programmes in the Serengeti.

Although excretion of attenuated vaccine virus has been recorded for some live distemper vaccines, there is no evidence that this 
occurs with the vaccine being used in the Serengeti trial, Nobivac Puppy DP (Intervet). In extensive tests, the attenuated virus has never been re-isolated from vaccinated dogs, nor has vaccine virus ever been transmitted to in-contact susceptibles. Vaccination trials of captive east African lions with Nobivac D (Intervet) also provide no evidence for virus excretion or transmission to in-contact susceptibles (R. Kock et al., unpublished data).

The chances of creating virus carriers through vaccination with Intervet distemper vaccines therefore appear to be low. However, even if virus excretion were to occur in a small fraction of dogs, the attenuated Onderstepoort strain of CDV (the distemper component of Nobivac vaccines) is much less pathogenic than the highly virulent strain of CDV currently circulating in northern Tanzania and Kenya. Nobivac D has been used safely in lions, foxes, minks and ferrets, whereas the strain of CDV recently isolated in east Africa is known to cause mortality in domestic dogs, lions, bat-eared foxes, hyaenas and leopards (Roelke-Parker et al, 1996; R. Kock et al., unpublished data).

The Serengeti domestic dog population is currently growing at a rate of at least 5 per cent per year, creating conditions that increasingly favour the persistence and transmission of infectious diseases. Clearly, it is undesirable if vaccination leads to a further growth in the dog population. Therefore, the impact of vaccination will be closely monitored throughout the trial by comparison of birth and death rates of dogs in vaccinated villages and unvaccinated control villages. Preliminary studies indicate that dog populations are likely to be closely regulated by owners to match supply and demand. If this turns out to be the case, rather than exacerbating disease risks, vaccination is likely to lower the likelihood of disease persistence by increasing life expectancy and reducing population turn-over rates. Although compulsory population control is not planned at this stage, the project will incorporate community education programmes to encourage greater responsibility of dog ownership which may lead to restriction of dog movements and voluntary breeding con- trol and to raise public health awareness (for control of human rabies).

The issue of sustainability of mass vaccination is also a valid concern. Preliminary studies indicate that the higher-density dog population to the west of the park is the sole reservoir of rabies and canine distemper in the Serengeti. If this hypothesis is correct, we should be able to protect wildlife by targeting mass vaccination efforts to a relatively small zone on the western borders of the park. Furthermore, preliminary studies indicate that a relatively low (and attainable) vaccination coverage level of 70 per cent should be sufficient to control infection in the domestic dog reservoir population. The proposed vaccination trial in Serengeti has been designed specifically to test these two hypotheses.

Funding for dog vaccination in the Serengeti has been secured until 2000, through Project Lifelion, the World Society for the Protection of Animals and the International Fund for Agricultural Development. With limited government budgets available for veterinary services, it is likely that long-term funding for sustained vaccination of dogs will have to be raised from wildlife revenues. Tourism and hunting both rely upon the presence of abundant and healthy wild carnivore populations. If domestic dog vaccination proves to be an effective way of controlling wild carnivore diseases, the cost of maintaining vaccination coverage seems a small price to pay to ensure the health of Serengeti's wildlife.

\section{Reference}

Roelke-Parker, M.E., Munson, L., Packer, C., Kock, R., Cleaveland, S., Carpenter, M., O'Brien, S.J., Pospischil, A., Hofmann-Lehmann, R., Lutz, H., Mwamengele, G.L.M., Mgasa, M.N., Machange, G.A., Summers, B.A. and Appel, M.J.G.A. 1996. Canine distemper virus epidemic in Serengeti lions Panthera leo. Nature, 379, 441-445.

Sarah Cleaveland

Department of Medical Parasitology

London School of Hygiene and Tropical Medicine Keppel Street, London WC1E 7HT, UK 